\title{
Indigenous Languages and English in the Globalised Modern Era in Brunei Darussalam
}

\author{
DAVID DETERDING \\ Universiti Brunei Darussalam, Brunei \\ dhdeter@gmail.com
}

Published online: 20 October 2020

To cite this article: David Deterding. 2020. Indigenous languages and English in the globalised modern era in Brunei Darussalam. KEMANUSIAAN the Asian Journal of Humanities 27(2): 165178. https://doi.org/10.21315/kajh2020.27.2.9

To link to this article: https://doi.org/10.21315/kajh2020.27.2.9

\begin{abstract}
This article considers two aspects of the linguistic situation in Brunei Darussalam in the globalised modern era: the situation with regard to minority indigenous languages: and the emergent status of Brunei English. Minority languages are threatened with extinction throughout the world and those in Brunei are no exception. There are seven officially recognised indigenous groups, each with its own language, though these are sometimes all claimed to be dialects of Malay_-Brunei Malay, Kedayan, Dusun, Bisaya, Tutong, Belait and Murut — but all these languages apart from Brunei Malay are under threat, even though some efforts are currently being undertaken to preserve them. English is also widely spoken in Brunei and Brunei English has features that make it distinct from other Englishes in the world. Some of these features are shared by other regional varieties of English and others are unique to Brunei. The article therefore, analyses the status of the minority languages of Brunei, describes efforts to preserve them and also evaluates the developing status of Brunei English as it evolves under the influences of globalisation; and it finally reflects on problems with neat classification into distinct languages.
\end{abstract}

Keywords and phrases: indigenous languages, language death, language preservation, Brunei English

\section{Introduction}

Brunei Darussalam (henceforth Brunei) is a small country in the north of the island of Borneo, with a size of 5,765 square kilometres and a population of about 428,000 people (United Nations 2019). Apart from the South China Sea to the north, it is surrounded by the Malaysian state of Sarawak, which separates the enclave of Temburong from the rest of the country (as shown in Figure 1). Although the 
country is small and the population is less than half a million, there is rich linguistic diversity. However, the minority indigenous languages are now all under threat.

Minority languages are threatened with extinction everywhere (Crystal 2002) and this is true in Southeast Asia just as much as in the rest of the world. In the globalised modern world, the ubiquitous availability of convenient interaction via the Internet is a double-edged sword for threatened languages: on the one hand, it allows people from shared backgrounds to keep in touch with each other and thereby continue to communicate using their heritage languages and furthermore it facilitates the sharing of recordings and other resources for minority languages via dedicated websites; yet at the same time it encourages people to interact with others from disparate backgrounds and most often they use global languages such as English for such international interactions. This extensive use of English over the Internet therefore threatens the continued existence of heritage languages, while English, as well as some regionally widely-used languages such as Malay, increasingly dominate cross-cultural communication.

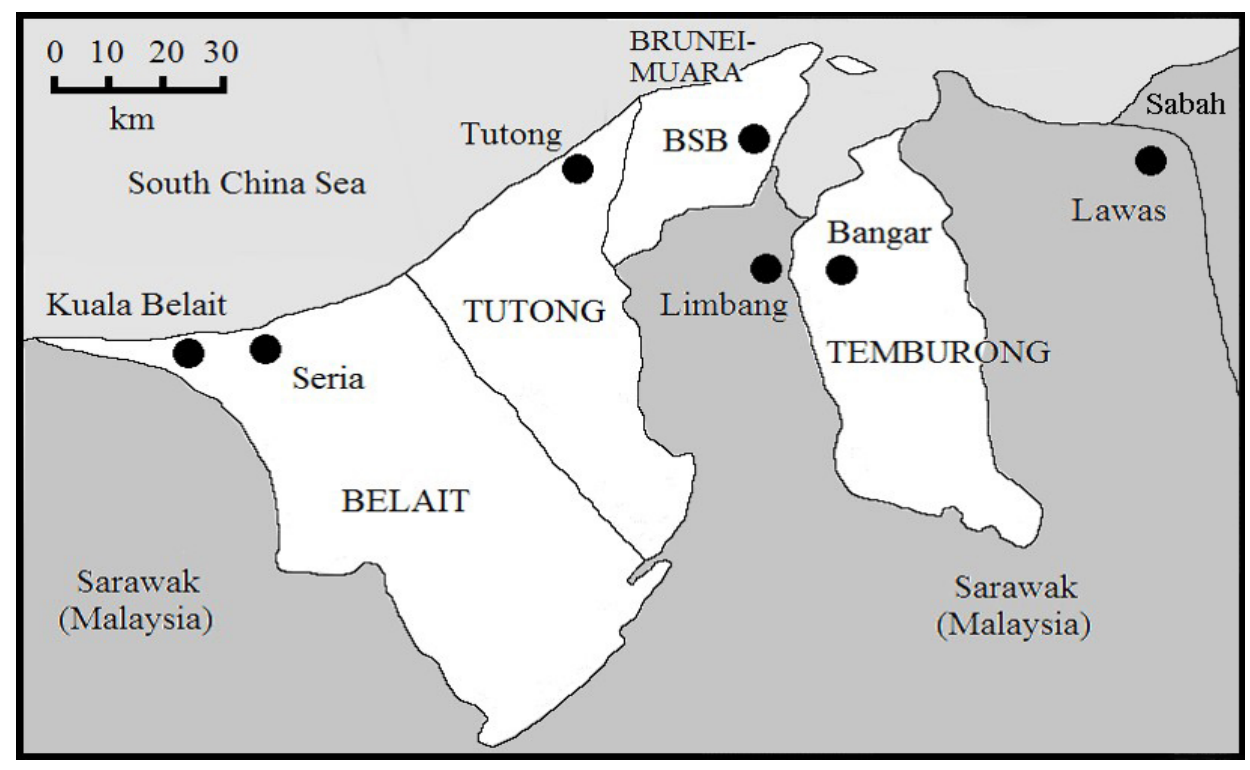

Figure 1. The four districts of Brunei: Brunei-Muara, Tutong, Belait and Temburong

This article considers two aspects of the linguistic situation in Brunei in the globalised modern era: the situation regarding the Austronesian languages that are officially recognised in Brunei; and the emergent status of Brunei English as it undergoes glocalisation, developing its own local identity while at the same time participating in global trends in the evolution of English. 


\section{Status of Indigenous Languages}

There are seven indigenous ethnic groups recognised in Brunei and each has its own language: Malay, Kedayan, Dusun, Bisaya, Tutong, Belait and Murut. Officially, these are described as dialects of Malay, but from a linguistic perspective, this classification is open to question, as they are not all mutually intelligible. This question of their status as dialects or as independent languages can be investigated further by analysis of the data in Dewan Bahasa dan Pustaka Brunei (DBPB) (2011), which provides a comparative list of about 2,000 words in all seven languages

One pattern found in the data in this book is illustrated in Table 1, showing the words for baik (good) and also jahit (to sew) in Standard Malay, Brunei Malay and the other six indigenous languages. It can be seen that in both cases the same word (or nearly the same word) occurs in Standard Malay, Brunei Malay and Kedayan (though Brunei Malay lacks a medial [h] in jahit). Furthermore, Dusun and Bisaya share the same word and Tutong and Belait are also linked. However, Murut is completely different.

Table 1. Words for baik (good) (DBPB 2011, 18) and jahit (to sew) (DBPB 2011, 115) in Standard Malay, Brunei Malay and the other six indigenous languages of Brunei

\begin{tabular}{|c|c|c|c|c|c|c|c|}
\hline $\begin{array}{c}\text { Standard } \\
\text { Malay }\end{array}$ & $\begin{array}{l}\text { Brunei } \\
\text { Malay }\end{array}$ & Kedayan & Dusun & Bisaya & Tutong & Belait & Murut \\
\hline baik & $\begin{array}{c}\text { baik } \\
\text { [bai?] }\end{array}$ & $\begin{array}{c}\text { baik } \\
\text { [bai?] }\end{array}$ & $\begin{array}{c}\text { moncoi } \\
\text { [mont]oi] }\end{array}$ & $\begin{array}{c}\text { moncoi } \\
\text { [mont]oi] }\end{array}$ & $\begin{array}{c}j i a \\
{\left[{\left.\mathrm{~d} z i \mathrm{a}^{2}\right]}^{2}\right.}\end{array}$ & $\begin{array}{c}\text { jie } \\
{\left[\mathrm{d}^{2} \mathrm{e}^{\mathrm{e}}\right]}\end{array}$ & $\begin{array}{c}d o \\
{[\text { do:?] }}\end{array}$ \\
\hline jahit & $\begin{array}{c}\text { jait } \\
\text { [dzait] }\end{array}$ & $\begin{array}{c}\text { jahit } \\
\text { [dzahit] }\end{array}$ & $\begin{array}{c}\text { mikit } \\
\text { [mikit] }\end{array}$ & $\begin{array}{c}\text { mikit } \\
\text { [mikit] }\end{array}$ & $\begin{array}{c}\text { jaroi } \\
\text { [dzayoi] }\end{array}$ & $\begin{array}{c}\text { jaroi } \\
\text { [dzaroi] }\end{array}$ & $\begin{array}{c}\text { nerut } \\
\text { [nərut] }\end{array}$ \\
\hline
\end{tabular}

An alternative pattern and one which is actually more common than that illustrated in Table 1, is that for the words batuk (cough) and hantu (ghost) shown in Table 2. Once again, Standard Malay, Brunei Malay and Kedayan have the same word (though, as with jahit in Table 1, Brunei Malay has no [h] in hantu). Similarly, Dusun and Bisaya share the same word in both cases but in Table 2, the words in Tutong and Belait are not connected. As before, Murut is completely different from all the others. 
Table 2. Words for batuk (cough) (DBPB 2011, 25) and hantu (ghost) (DBPB 2011, 102) in Standard Malay, Brunei Malay and the other six indigenous languages of Brunei

\begin{tabular}{|c|c|c|c|c|c|c|c|}
\hline $\begin{array}{c}\text { Standard } \\
\text { Malay }\end{array}$ & $\begin{array}{l}\text { Brunei } \\
\text { Malay }\end{array}$ & Kedayan & Dusun & Bisaya & Tutong & Belait & Murut \\
\hline batuk & $\begin{array}{l}\text { batuk } \\
\text { [batø?] }\end{array}$ & $\begin{array}{l}\text { batuk } \\
\text { [bato?] }\end{array}$ & $\begin{array}{l}\text { bagusai } \\
\text { [bagusai] }\end{array}$ & $\begin{array}{l}\text { bagusai } \\
\text { [bagusai] }\end{array}$ & $\begin{array}{l}\text { iod } \\
\text { [iod] }\end{array}$ & $\begin{array}{l}\text { nyangied } \\
\text { [nayicd] }\end{array}$ & $\begin{array}{l}\text { mariek } \\
\text { [mariə?] }\end{array}$ \\
\hline hantu & $\begin{array}{l}\text { antu } \\
{\left[\mathrm{antu}^{2}\right]}\end{array}$ & $\begin{array}{l}\text { hantu } \\
\text { [hantu? }]\end{array}$ & $\begin{array}{l}\text { lamatai } \\
\text { [lamatai] }\end{array}$ & $\begin{array}{l}\text { lamatai } \\
\text { [lamatai] }\end{array}$ & $\begin{array}{l}\text { bali } \\
{\left[\text { bali }^{\mathrm{h}}\right]}\end{array}$ & $\begin{array}{l}\text { akang } \\
\text { [akay] }\end{array}$ & $\begin{array}{l}\text { ada } \\
{\left[{ }^{\mathrm{h}} \mathrm{da}^{?}\right]}\end{array}$ \\
\hline
\end{tabular}

An analysis of the relationship between these languages is shown in Table 3, which estimates the level of shared lexis of the first 255 words listed in DBPB (2011). These figures suggest that Standard Malay, Brunei Malay and Kedayan are indeed dialects of Malay, with over $75 \%$ of lexical cognates in all cases, but the level of lexical cognates between these three varieties and the other five varieties is rather lower, so from a linguistic point of view, they should be regarded as different languages. Furthermore, it is clear that Dusun and Bisaya are closely linked, with a shared lexicon of $76.6 \%$, but there is little evidence of Tutong and Belait being linked, as has sometimes been suggested. Finally, Murut is quite distinct from all the others.

Table 3. Percentages of lexical cognates between Standard Malay, Brunei Malay and the other six indigenous languages of Brunei based on the first 255 words in DBPB (2011)

\begin{tabular}{lcccccccc}
\hline & $\begin{array}{c}\text { Standard } \\
\text { Malay }\end{array}$ & $\begin{array}{c}\text { Brunei } \\
\text { Malay }\end{array}$ & Kedayan & Dusun & Bisaya & Tutong & Belait & Murut \\
\hline $\begin{array}{l}\text { Standard } \\
\text { Malay }\end{array}$ & - & 75.7 & 76.5 & 41.4 & 47.6 & 56.1 & 37.2 & 31.6 \\
Brunei & 75.7 & - & 88.2 & 49.6 & 54.3 & 62.4 & 39.1 & 30.9 \\
Malay & & & & & & & & \\
Kedayan & 76.5 & 88.2 & - & 48.0 & 50.4 & 58.8 & 37.9 & 33.2 \\
Dusun & 41.4 & 49.6 & 48.0 & - & 76.6 & 48.0 & 32.5 & 29.8 \\
Bisaya & 47.6 & 54.3 & 50.4 & 76.6 & - & 49.6 & 33.6 & 32.1 \\
Tutong & 56.1 & 62.4 & 58.8 & 48.0 & 49.6 & - & 45.3 & 34.1 \\
Belait & 37.2 & 39.1 & 37.9 & 32.5 & 33.6 & 45.3 & - & 31.2 \\
Murut & 31.6 & 30.9 & 33.2 & 29.8 & 32.1 & 34.1 & 31.2 & - \\
\hline
\end{tabular}

The figures shown in Table 3 are all somewhat lower than those reported by Nothofer (1991), who presented the results of a similar comparison. For example, he reported an $80 \%$ level of shared lexicon between Standard Malay and Kedayan 
and $82 \%$ between Dusun and Bisaya. There are three principle possibilities for this difference: (1) there may have been a shift in usage between 1991 and 2011; (2) Nothofer based his comparison on the Swadesh list of 200 common terms, words like "house", "wife", "to come" and "to plant", while there is a wider range of words in DBPB (2011) and it might be true that common words are more likely to be shared - for example, mata (which means "eye") is shared by all the languages (DBPB 2011, 190); and (3) the methodology of assessing shared cognates may differ. In obtaining the results in Table 3 , in cases in which two or more words are shown in DBPB (2011), only the first was considered. For example, for the Standard Malay word botak (bald), two options are listed for Brunei Malay (gundul and jugul) and two are also listed for Kedayan (jugul and lasak). While it is obvious that none of these is linked with botak, so in this case both Brunei Malay and Kedayan are clearly distinct from Standard Malay, we might note that the second Brunei Malay option—jugul — matches the first option listed for Kedayan. In adopting the methodology of considering only the first word listed in each case, Brunei Malay and Kedayan are regarded as having different words for "bald", but an alternative methodology that acknowledged some of the alternatives may match would provide higher rates of shared lexicon than those in Table 3.

\section{Vitality of the Indigenous Languages}

Despite the official recognition of these minority languages reflected in the publication of DBPB (2011), all of them apart from Brunei Malay are threatened with extinction. Table 4 shows the "vitality rating" for each of these languages on a scale of 6 (Healthy) to 0 (Extinct) suggested by Noor Azam and Siti Ajeerah (2016). These figures show that all these languages except for Brunei Malay are under severe threat and that Belait is now almost extinct.

Table 4. Vitality rating for the seven indigenous languages of Brunei

\begin{tabular}{lc}
\hline Language & Vitality rating \\
\hline Brunei Malay & 6.0 \\
Kedayan & 2.0 \\
Dusun & 2.0 \\
Bisaya & 2.0 \\
Tutong & 2.5 \\
Belait & 0.1 \\
Murut & 2.0 \\
\hline
\end{tabular}

Source: Noor Azam and Siti Ajeerah $(2016,21)$ 
Compared with earlier estimates offered by Martin (1995), Brunei Malay, Dusun and Tutong remain unchanged, but the situation for Kedayan, Bisaya, Belait and Murut has worsened in the intervening 21 years.

Coluzzi (2010) offers a more optimistic prognosis for Murut based on his research in Temburong District, the enclave that is separated from the rest of Brunei by the Malaysian district of Limbang (as shown in Figure 1), and he notes that Murut benefits from support for Lun Bawang (the alternative name for the language) offered in Malaysia, where it is the most commonly spoken indigenous language in Lawas, the town in Sarawak that is situated between Temburong and the East Malaysian state of Sabah. However, even with this relatively optimistic prognosis, it is still true that Murut is under threat in Brunei, largely because of the dominance of Malay.

The pressure from Malay in Brunei can be illustrated by the existence of a sign by the side of a road in the capital Bandar Seri Begawan (BSB) (as shown in Figure 2), reminding people (in both Jawi and Roman script) that Malay is the official language of the country. There are a number of instances of this sign in $\mathrm{BSB}$, and it is uncertain what their purpose is: Does the government feel that Malay is threatened by the widespread use of English? Or perhaps there is official concern that people tend to use Brunei Malay rather than Standard Malay, so they need to be reminded to use Standard Malay? Nevertheless, the sign illustrates official promotion of Malay and it reflects little support for the other indigenous languages in Brunei.

There is a mural on the national library building in the centre of BSB (as shown in Figure 3) which includes the words berbahasa satu, berbangsa satu, bernegara satu (one language, one race, one nation). This further reflects the fact that, in the past, there has been little official encouragement for the preservation of multilingual ethnic diversity and it seems that the government would be quite happy if everyone spoke Malay.

Indeed, Coluzzi (2012) has confirmed that there is no evidence of the minority languages such as Kedayan or Dusun appearing on public signs in Brunei; and Noor Azam has likened the plight of the minority languages in the country to children suffering from the conflicts of duelling aunties, in this case, Malay and English. 


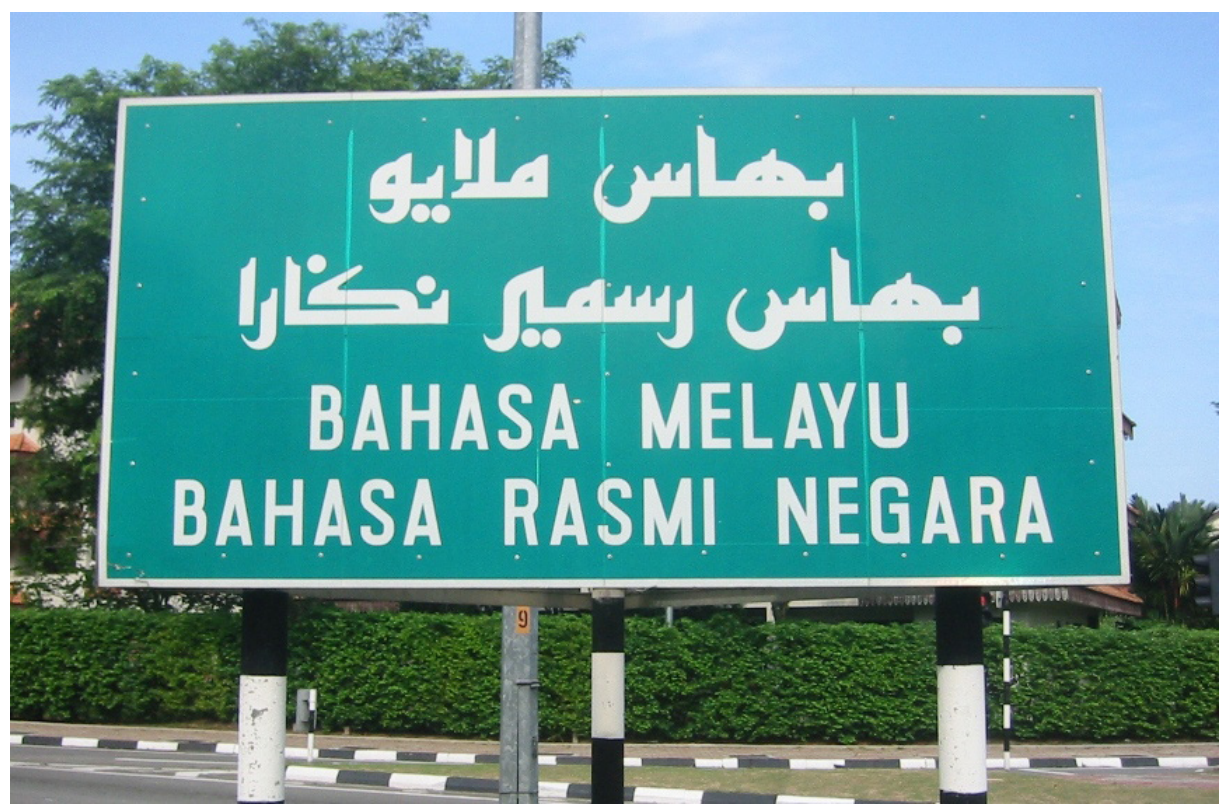

Figure 2. Road sign in BSB reminding people that "The Malay language is the official language of the country"

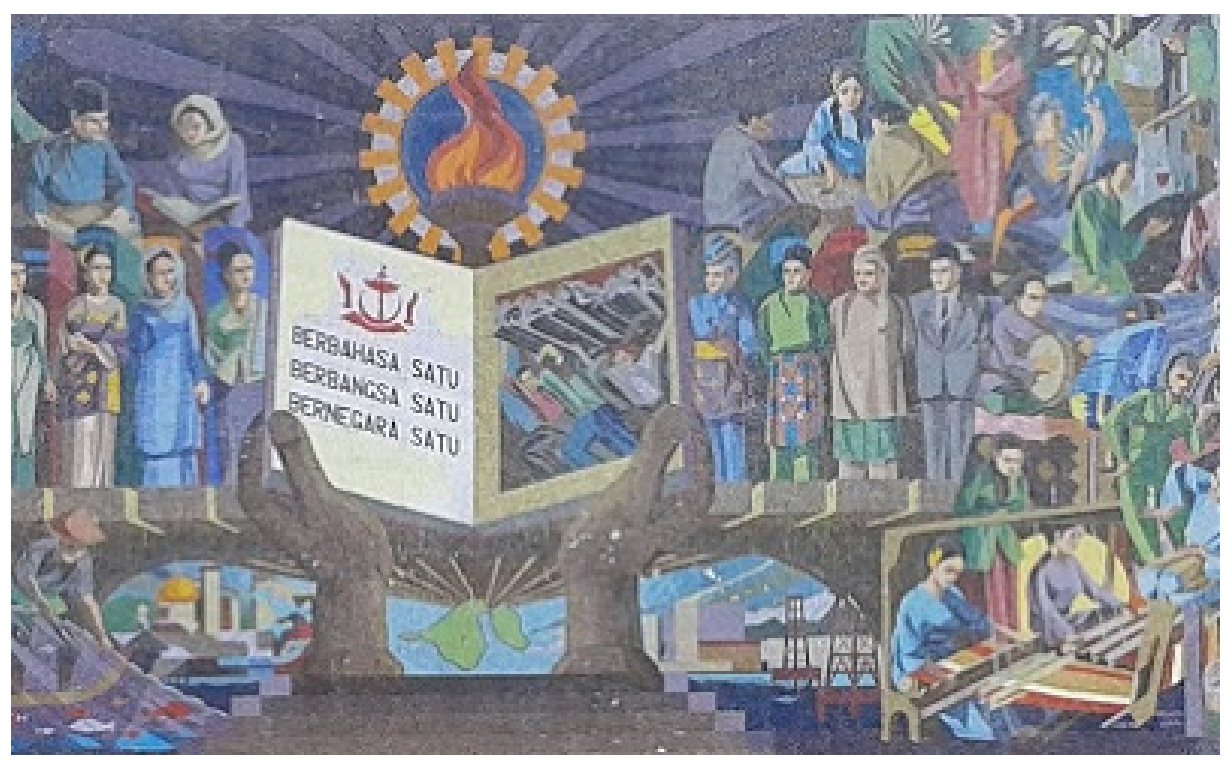

Figure 3. Mural on the national library in BSB promoting "one language, one race, one nation" 


\section{Resources for the Minority Indigenous Languages in Brunei}

Despite the gloomy prognosis for the survival of the minority languages shown in Table 2 and official pressure on people to speak Malay as illustrated in Figures 2 and 3 , there is nowadays actually some evidence of official support for the minority indigenous languages, even if this is not reflected in the linguistic landscape of public signs in the capital. In addition to DBPB (2011), excellent dictionaries have been published for Brunei Malay (DBPB 2007), Kedayan (DBPB 2006) and Tutong (DBPB 2010), representing substantial resources for preserving these languages. One hopes that similar dictionaries might appear for the other languages: Dusun, Bisaya, Belait and Murut.

In some places, attempts have been made to label plants with their traditional names. Figure 4 shows some plant labels found along the forest boardwalk near Tasek Merimbun, a scenic lake in the south of Tutong District. It is encouraging that such efforts have been made to preserve the traditional names of these plants.
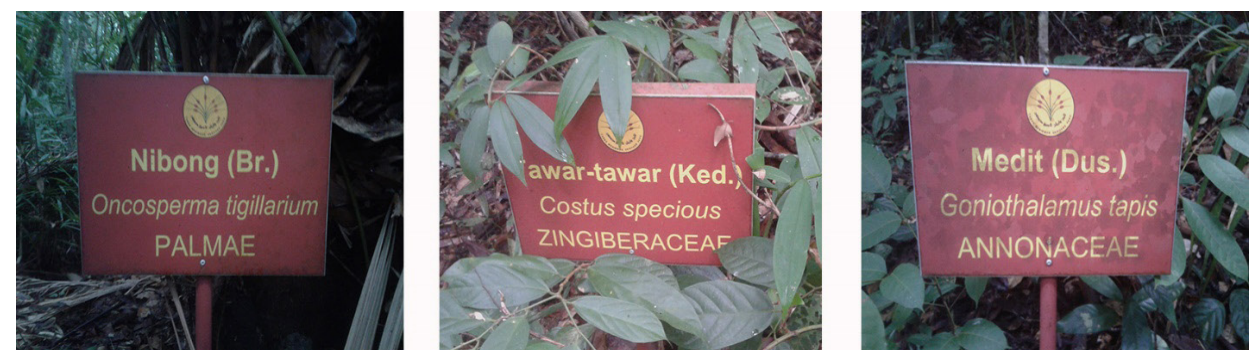

Figure 4. Plant names in Brunei Malay, Kedayan and Dusun respectively

As noted in the introduction, the Internet provides the opportunity to share resources for threatened languages. Websites have been constructed for Brunei Malay (Deterding 2017) to allow listeners to listen to the materials published in Deterding and Ishamina (2017) and also for Dusun (Deterding 2019) to let people hear the materials from Gardiner, Deterding and Yabit (2019). Current work is progressing for Kedayan and future work is planned for Bisaya. One hopes that online support of this kind can be provided for all the minority languages in Brunei.

Finally, the Language Centre at Universiti Brunei Darussalam offers some courses in Dusun and Tutong and these have proved popular with students (Noor Azan and Siti Ajeerah 2016, 21).

Only time will tell how effective the publishing of dictionaries, the labelling of plants, the provision of online resources for analysing and listening to materials 
and the availability of courses in the minority languages will prove in preserving them.

\section{Status of English in Brunei}

Though Brunei Malay is dominant as the basic lingua franca throughout the country, English is also widely spoken, especially by well educated people. A bilingual education system was implemented in 1985, to ensure that students grew up speaking their national language while at the same time being proficient in English (Jones 1996). Ożóg (1996, 159) suggested that, in Brunei, Malay was the language of the soul, while English had a more utilitarian role in providing access to the outside world. While this is probably still largely true today, McLellan and Noor Azam (2014) note that an increasing number of children have English as their first language, so one wonders to what extent Malay is the language of the soul for them. Indeed, the implementation in 2009 of a new education policy, termed "Sistem Pendidikan Negara Abad ke-21" (SPN21) (National Education System for the 21st Century) seems to have strengthened the position of English at the expense of Malay, especially as Mathematics and Science are now taught in English from the start of primary school (Salbrina and Jainatul 2019).

Although English is widely used, it is not the same as English spoken elsewhere, as Brunei English has features that make it distinct from other varieties of English in the world (Deterding and Salbrina 2013). Features of Brunei English pronunciation include: (1) the use of [t] and [d] for the voiceless and voiced TH sounds, the sounds at the start of words such as "thin" and "this", (2) increasingly prevalent rhoticity among all young Bruneians (Nur Raihan 2017), (3) the merging of the TRAP and FACE vowels (using the lexical keywords suggested by Wells [1982]), with the result that "pant" and "paint" may become homophones, (4) the avoidance of reduced vowels, especially in function words such as "of", "as" and "than" and (5) the use of spelling pronunciation, such as the occurrence of [1] in "salmon" and [p] in the first syllable of "company". Grammatical features include the use of plural nouns for logically plural entities, such as "furnitures" and "equipments" (as shown in Figure 5) and the occurrence of a singular noun after "one of", such as in the phrase "one of my aunt". 

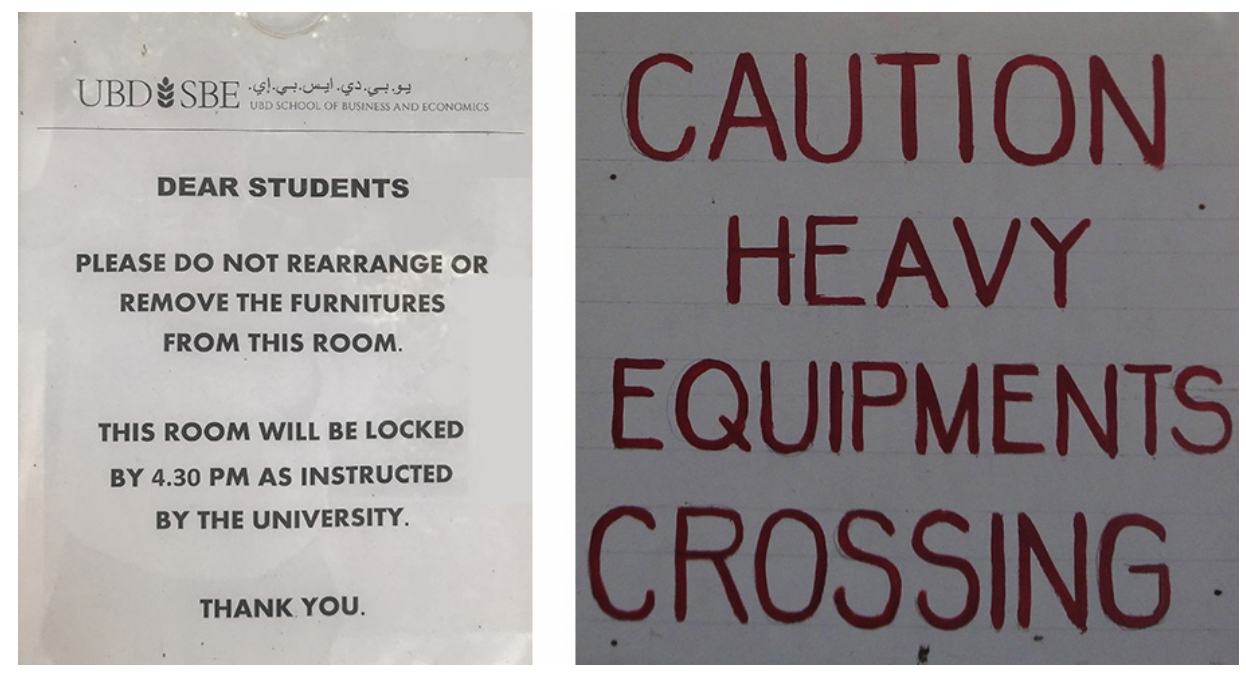

Figure 5. Signs seen on the Universiti Brunei Darussalam campus, illustrating the use of the plural nouns "furnitures" and "equipments"

Brunei English also has lexical innovations, largely derived by means of borrowings from Malay to describe local culture, including titah for a speech by His Majesty the Sultan, tudong for an Islamic head-dress for women and ambuyat for a local food made from sago.

Some of these features of Brunei English reflect global trends. For example, spelling influences pronunciation throughout the world (Deterding and Nur Raihan 2016). Wells $(2008,317)$ reports that "forehead" is pronounced with a medial [h] by most people, especially by young people, and this reflects the spelling of the word, so the traditional pronunciation that rhymed with "horrid" is now rare. While "salmon" with medial [1] is not listed as a possibility by Wells $(2008,708)$, its occurrence in world varieties of English is common and one suspects it might become the norm everywhere one day. Other features, such as the use of $[\mathrm{t}]$ and [d] for the $\mathrm{TH}$ sounds and the avoidance of vowel reduction, are also common throughout the world, particularly in Southeast Asia (Deterding and Kirkpatrick 2006). In contrast, the extensive use of rhoticity sets Brunei English apart from the English of most speakers in Singapore (Tan 2012) and also Malaysia, and the merging of TRAP and FACE has not been widely reported for other Englishes. In some ways, therefore, Brunei English is participating in global trends, in other ways it may reflect regional usage and in some respects it is developing its own distinct identity. 
For grammar and lexis, similar trends can be observed: "furnitures" occurs in most varieties of world English in Africa and Asia (Mesthrie and Bhatt 2008, 53), but the extent of singular nouns after "one of" needs to be investigated. Mesthrie and Bhatt $(2008,52)$ note "one of the worksheet" for some native-American speakers of English, but it is unclear how widespread this might be. Use of words such as titah and tudong is common in the region, especially in Malaysia and Indonesia, so the adoption of these words in Brunei English might be regarded as a regional innovation. However, foods such as ambuyat may only be found in Brunei and even for Malay, the online Malay dictionary provided by the Dewan Bahasa dan Pustaka in Malaysia (2017) includes no entries for this word. So, once again, we find some global trends (furnitures), some regional lexis (tudong) and some uniquely Bruneian words (ambuyat).

We might finally consider the developmental status of English in Brunei. Schneider (2007) has proposed a five-phase model of the dynamic evolution of post-colonial Englishes, starting from the first stage in which English arrives in a new territory to the fifth stage in which it is a fully mature variety in its own right. Unfortunately, he makes no mention of Brunei, but Deterding and Salbrina $(2013,119)$ suggest that it may be in phase three, termed "nativisation". This would place it at a similar stage as Malaysian English though less well advanced in its evolution than Singapore English which is assumed to be in phase four (Schneider 2007, 160). It will be interesting to see if Brunei English continues in this evolutionary trajectory or if the pressures of globalisation put a break on the emergence of distinct local varieties.

\section{Discussion}

This article has provided an analysis of the status of the indigenous languages of Brunei, an overview of some efforts to preserve them and a discussion of the status of Brunei English. But perhaps trying to analyse the different languages in Brunei as distinct entities is flawed. In the modern globalised world, languages no longer belong in distinct boxes that can be neatly labelled (though this begs the question about whether they ever did belong in such boxes) and Blommaert (2010) asks what it means to claim that one speaks a language such as French. With whom? Under what circumstances? Technical French or colloquial French? We do not really know any language in its entirety, but at the same time most of us are proficient to some degree in a range of languages, so each person has a unique repertoire of linguistic abilities at their disposal. And this trend is certain to continue under the pressures of globalisation. Furthermore, we should note that code-switching is exceptionally common in Brunei, to the extent that it is often 
impossible to specify if someone is speaking Malay or English, or whether we should regard the mixed code as a language in its own right (McLellan 2010).

At the same time, it is not really possible to compartmentalise languages cleanly. Are Dusun and Bisaya different languages or not? When the data for the pronunciation of Dusun in Gardiner, Deterding and Yabit (2019) was being collected, the informant sometimes disagreed with the listing in DBPB (2011), claiming that some words that are labelled as Dusun are in fact Bisaya and vice versa; so maybe Dusun and Bisaya are irretrievably merged. Similarly, are Brunei Malay and Kedayan really distinct? A defining characteristic of Kedayan is that it has no [r] (Martin and Poedjosoedarmo 1996, 9), but current work on the analysis of Kedayan shows that the informant does occasionally have [r], including in dai (from) pronounced as [dari] with a tapped medial [r]. This seems to be an influence from Brunei Malay, so we should ask ourselves, "Does pure Kedayan still exist?". Maybe most speakers of Kedayan actually speak something that exists along a continuum of Brunei Malay and Kedayan.

Despite problems such as these in the neat classification of languages, it still remains true that the six minority indigenous languages of Brunei are under severe threat of becoming extinct. The death of traditional languages represents the loss of part of the ethnic heritage of a country, so it is hoped that further efforts can be undertaken to preserve them before they succumb to the relentless onslaught of globalisation.

\section{References}

Blommaert, J. 2010. The sociolinguistics of globalization. Cambridge: Cambridge University Press. https://doi.org/10.1017/CBO9780511845307

Coluzzi, P. 2012. The linguistic landscape of Brunei Darussalam: Minority languages and the threshold of literacy. Southeast Asia: A Multidisciplinary Journal 12: 1-16.

2010. Endangered languages in Borneo: A survey among the Iban and Murut (Lun Bawang) in Temburong Brunei. Oceanic Linguistics 49(1): 119-143. https://doi.org/10.1353/ol.0.0063

Crystal, D. 2002. Language death. Cambridge: Cambridge University Press.

Deterding, D. 2019. The pronunciation of Dusun. Retrieved from http://fass.ubd.edu.bn/research/ dusun/index.html (accessed 9 August 2019).

2017. The pronunciation of Brunei Malay. Retrieved from http://fass.ubd.edu.bn/research/ brunei-malay/index.html (accessed 9 August 2019).

Deterding, D. and Kirkpatrick, A. 2006. Emerging South-East Asian Englishes and intelligibility. World Englishes 25(3/4): 391-409. https://doi.org/10.1111/j.1467-971X.2006.00478.x

Deterding, D. and Nur Raihan Mohamad. 2016. Spelling pronunciation in English. ELT Journal 17: 87-91. https://doi.org/10.1093/elt/ccw073

Deterding, D. and Salbrina Sharbawi. 2013. Brunei English: A new variety in a multilingual society. Dordrecht, Netherlands: Springer. https://doi.org/10.1007/978-94-007-6347-0 
Dewan Bahasa dan Pustaka. 2017. Pusat Rujukan Persuratan Melayu. Retrieved from http://prpm. dbp.gov.my/ (accessed 10 August 2019).

Dewan Bahasa dan Pustaka Brunei (DBPB). 2011. Daftar leksikal 7 dialek Brunei Darussalam. Bandar Seri Begawan: DBPB.

2010. Kamus Tutong-Melayu Melayu-Tutong. 2nd Ed. Bandar Seri Begawan: DBPB.

2007. Kamus Bahasa Melayu Brunei. 2nd Ed. Bandar Seri Begawan: DBPB.

2006. Kamus Kedayan-Melayu Melayu-Kedayan. Bandar Seri Begawan: DBPB.

Gardiner, I.A., Deterding, D. and Yabit Alas. 2019. The pronunciation of Dusun. South East Asia: A Multidisciplinary Journal 19: 14-21.

Jones, G.M. 1996. The Brunei education policy in Brunei Darussalam. In Language use and language change in Brunei Darussalam, eds. P.W. Martin, C. Ożóg and G. Poedjosoedarmo, 123-132. Athens, OH: Ohio University Center for International Studies.

Martin, P.W. 1995. Whither the indigenous languages of Brunei Darussalam? Oceanic Linguistics 34: 44-60.

Martin, P.W. and Poedjosoedarmo, G. 1996. An overview of the language situation in Brunei Darussalam. In Language use and language change in Brunei Darussalam, eds. P.W. Martin, C. Ożóg and G. Poedjosoedarmo, 1-23. Athens, OH: Ohio University Center for International Studies.

McLellan, J. 2010. Mixed codes or varieties of English? In The Routledge handbook of world Englishes, ed. A. Kirkpatrick, 425-441. London/New York: Routledge.

McLellan, J. and Noor Azam Haji-Othman. 2014. English in Brunei: Challenges and future directions. World Englishes 33(4): 486-497. https://doi.org/10.1111/weng.12109

McLellan, J., Noor Azam Haji-Othman and Deterding, D. 2016. The language situation in Brunei Darussalam. In The use and status of language in Brunei Darussalam: A kingdom of unexpected linguistic diversity, eds. Noor Azam Haji-Othman, J. McLellan and D. Deterding, 9-16. Singapore: Springer. https://doi.org/10.1007/978-981-10-0853-5_2

Mesthrie, R. and Bhatt, R.M. 2008. World Englishes: The study of news linguistic varieties. Cambridge: Cambridge University Press. https://doi.org/10.1017/CBO9780511791321

Noor Azam Haji-Othman. 2012. Is it always English? "Duelling aunties" in Brunei Darussalam. English language as Hydra: Its impact on non-English language cultures, eds. C. Rapatanaha and B. Bunce, 175-190. Clevedon, UK: Multilingual Matters. https://doi. org/10.21832/9781847697516-016

Noor Azam Haji-Othman and Siti Ajeerah Najib. 2016. The state of indigenous languages in Brunei. In The use and status of language in Brunei Darussalam: A kingdom of unexpected linguistic diversity, eds. Noor Azam Haji Othman, J. McLellan and D. Deterding, 17-28. Singapore: Springer. https://doi.org/10.1007/978-981-10-0853-5_3

Nothofer, B. 1991. The languages of Brunei Darussalam. In Papers in Austronesian linguistics, ed. H. Steinhauer, 151-176. Canberra: Australian National University.

Nur Raihan Mohamad. 2017. Rhoticity in Brunei English: A diachronic approach. South East Asia: A Multidisciplinary Journal 17: 1-17.

Ożóg, A.C.K. 1996. The unplanned use of English: The case of Brunei Darussalam. In Language use and language change in Brunei Darussalam, eds. P.W. Martin, C. Ożóg and G. Poedjosoedarmo, 156-172. Athens, OH: Ohio University Center for International Studies.

Salbrina Sharbawi and Jainatul Halida Jaidin. 2019. Brunei's SPN21 English language-in-education policy: A macro-to-micro evaluation. Current Issues in Language Planning 21(2): 175-201. https://doi.org/10.1080/14664208.2019.1657267

Schneider, E.W. 2007. Postcolonial English: Varieties around the world. Cambridge: Cambridge University Press. https://doi.org/10.1017/CBO9780511618901 
Susilawati Japri. 2016. The language of shop signs in a modern shopping centre in Brunei. In The use and status of language in Brunei Darussalam: A kingdom of unexpected linguistic diversity, eds. Noor Azam Haji Othman, J. McLellan and D. Deterding, 29-38. Singapore: Springer. https://doi.org/10.1007/978-981-10-0853-5_4

Tan, Y. 2012. To r or not to r: Social correlates of /./ in Singapore English. International Journal of the Sociology of Language 218: 1-24. https://doi.org/10.1515/ijsl-2012-0057

United Nations. 2019. Permanent mission of Brunei Darussalam to the United Nations: Country facts. Retrieved from https://www.un.int/brunei/brunei/country-facts (accessed 10 September 2019).

Wells, J.C. 2008. Longman pronunciation dictionary. Harlow, UK: Longman.

1982. Accents of English. Cambridge: Cambridge University Press. https://doi.org/10.1017/ CBO9780511611759 